\title{
振動法による薄板の張力分布同定技術の開発*
}

在原 広敏 ${ }^{* 1}$, 岡田 徹 ${ }^{* 1}$, 齊藤 裕紀 ${ }^{* 2}$, 井上 喜雄 ${ }^{* 3}$

\section{Identification of Tension Distribution of Thin Plate Using Vibration Characteristics}

\author{
Hirotoshi ARIHARA*1, Toru OKADA, Hironori SAITO and Yoshio INOUE \\ ${ }^{* 1}$ Kobe Steel Ltd., Technical Development Group \\ 1-5-5, Takatsukadai, Nishi-ku, Kobe, Hyogo, 651-2271, Japan
}

\begin{abstract}
A high-accuracy measurement technique for plate tension distribution on the process line would potentially lead to improved steel, aluminum and copper plate qualities. We propose an identification method by using natural frequencies and vibration modes, which are related to tension distributions of thin plate. In this paper, a new tension identification method in a thin plate using characteristics of vibration is investigated. We develop a simplified dynamic model of thin plate, and tension distribution is modeled by springs. A simplified model spring constants are obtained by the least-squares method to minimize the difference between a simplified model modal parameters and the given values. We apply the proposed identification method to a thin aluminum plate based on FEM analysis results. As a result, it is shown that identified tension distributions well corresponded to the FEM results.
\end{abstract}

Key Words : Identification of Tension Distribution, Thin Plate, FEM, Modal Analysis

\section{1. 緒}

鉄板や銅板，アルミ板などの薄板生産ラインにおいて圧延や熱処理により薄板にはさまざまな形状不良が生じ る. とくに圧延時にはロールのたわみや板の元形状，加工熱による熱変形の影響を受けるため，同一の板上に長 さの差ができて微妙にゆがむような形状となることがある。このような形状不良は無張力状態では板が座屈して 平坦度を悪化させる原因となる．薄板製品の品質を確保するためにはこのようなゆがみを管理して，なるべく小 さくすることが重要である，そのためさまざまなラインに低コストで簡便に適用できるゆがみ分布計測システム が求められている，薄板の幅方向のゆがみ分布を計測する装置としては分割ロールにロードセルを埋め込んだ接 触式のロール法がある(1). しかしながら薄板表面への疪つきやロール摩耗等への配慮が必要となること, また口 一ル設置のためのコストと設置スペースの確保が必要になるなどの課題がある．また，通板中の板の平坦度を非 接触で直接計測する方法としてレーザ式や渦電流式の変位計を用いた平坦度測定法, 走查レーザを用いた光切断 法(2)などが知られている. しかしながら薄板ラインでは板に一定の張力を付加しながら通板するのが一般的であ り, 微小なゆがみ形状は引き伸ばされて見かけ上は平坦な形状となるため, 形状計による計測が困難であること が多い，その一方で板の内部には引き伸ばされたゆがみ分布に対応した張力分布が発生しており, 板の振動特性 から幅方向の張力分布を求めることができればゆがみ分布を推定することが可能である．従来の研究において振 動法により板の総張力を固有振動数から直接同定する方法が提案されており, 比較的単純な理論と測定機器構成 で非接触の計測が可能となっている(3). そこで，本研究ではゆがみ分布計測技術開発の前段階として従来の振動 法による張力同定法を発展させ，ゆがみ分布を有する薄板の幅方向の固有振動数と振動モードより張力分布を求 める方法を開発した．また，開発した手法を FEM 解析結果に適用し，その妥当性を検証した.

\footnotetext{
* 原稿受付 2011 年 11 月 29 日

*1 正員，（株)神戸製鋼所 神戸総合技術研究所（广651-2271 兵庫県神戸市西区高塚台 1-5-5）

*2 (株) 神戸製鋼所 真岡製造所（下321-4367 杤木県真岡市鬼怒ヶ丘 15 番地）

*3 正員, フェロー，高知工科大学（一782-8502 高知県香美市土佐山田町宮ノ口 185）

E-mail: arihara.hirotoshi@kobelco.com
} 


\section{2. 薄板のモデル化}

図 1(a)に示すような幅方向にゆがみ分布を有する薄板に対して長手方向に張力を付加した場合，板を短冊状の 領域に分割すると図 1(b)ようにゆがみの大きい部分の張力は低く，ゆがみの小さい部分の張力は高くなる．それ ぞれの短冊には張力による幾何剛性が発生するから板全体の張力分布を等価剛性分布とみなして図 1(c) のように モデル化することができると考えられる。ここで薄板のゆがみが板幅方向および長手方向について分布している 場合は板面内における 2 次元の等価剛性分布を考慮する必要があるが，例えば薄板の圧延時において一定の圧延 条件であれば板の長手方向のゆがみ分布は板を支持するロールの間隔内においてはほぼ一様とみなせる.そこで, 張力分布は幅方向のみ考慮してばね分布とし, 薄板を長手方向の中央部に縮小した図 2 に示すような簡易モデル を作成した。

簡易モデルでは質量 $m$ と重心点回りの慣性モーメント $J$ を持つ長さ $l$ の剛体要素をピンで連結したリンクモデ ルで薄板を表現した. 幅方向に分布した振動変位 $z$ は $l$ に対して十分に小さいとして要素の回転変位 $\theta$ を $z_{i+1}-z_{i} \fallingdotseq l \theta_{i}$ と近似し，節点の自由度は並進方向のみとした．よって簡易モデルでは薄板を幅方向に $n-1$ 等分割して節点を配 置した場合は自由度 $n$ となる．また，薄板の長手方向の曲げ剛性は十分小さいとして無視し，幅方向の曲げ剛性 $\tau$ を要素間の回転ばねとして，張力分布は各節点に配置したばね分布 $k_{i}(i=1 \sim n)$ でモデル化した.

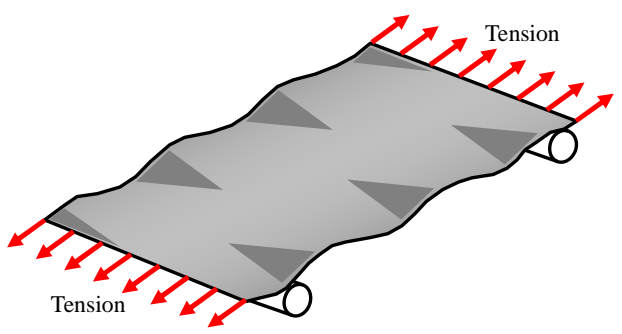

(a) Strain pattern of plate

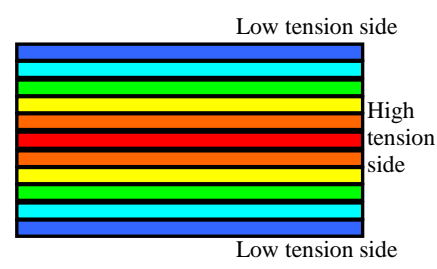

(b) Tensile pattern of plate

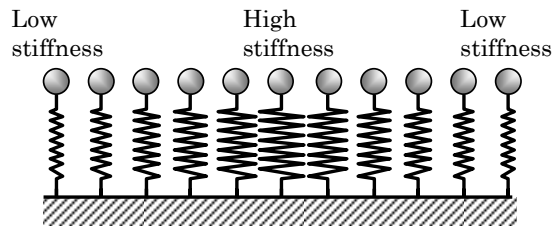

(c) Equivalent stiffness distribution

Fig.1 Tensile pattern modelling of thin plate

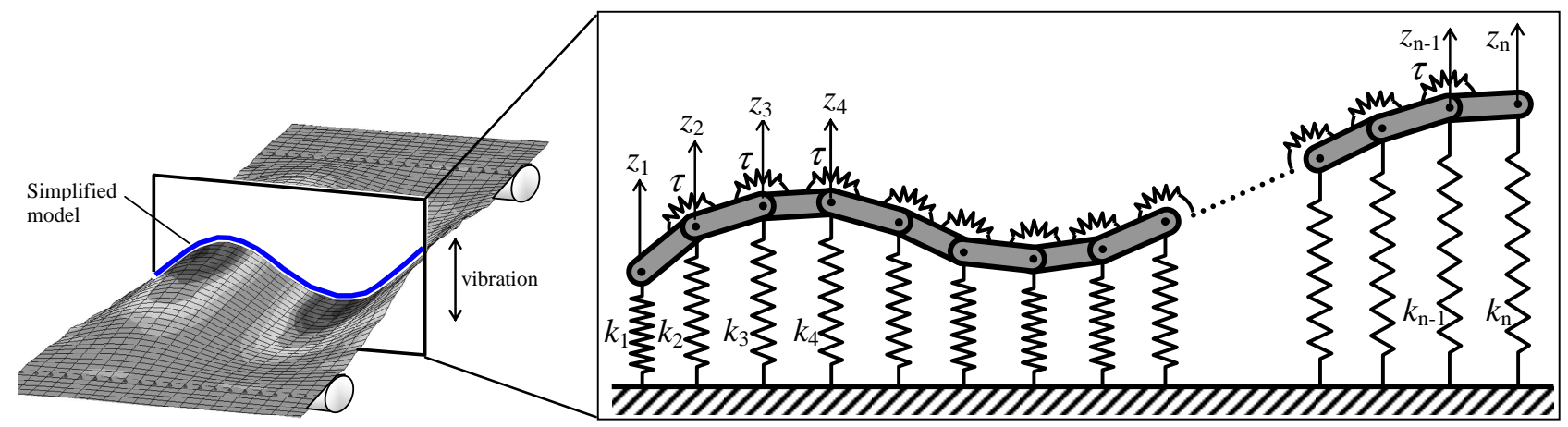

Fig.2 Simplified dynamic link model of thin plate

式(1)に図 2 に示した簡易モデルの運動方程式を示寸. 式(1)中の $\mathbf{M}$ は質量マトリクス， $\mathbf{K}$ は剛性マトリクス， $z$ は各節点における変位ベクトルである． $\mathbf{K}_{\tau}$ と $\mathbf{K}_{T}$ はそれぞれ剛性マトリクスの曲げ岡性成分と張力成分である. $\mathbf{K}_{T}$ は同定対象となるばね分布 $k_{i}(i=1 \sim n)$ を対角要素とする未知行列, $\mathbf{M}$ および $\mathbf{K}_{\tau}$ は板の寸法, 物性より算出され る既知行列である.

$$
\begin{aligned}
& \mathbf{M} \ddot{z}+\mathbf{K} z=\mathbf{0} \\
& \boldsymbol{z}=\left\{\begin{array}{llll}
z_{1} & z_{2} & \cdots & z_{n}
\end{array}\right\}^{T}
\end{aligned}
$$




$$
\mathbf{M}=\left[\begin{array}{cccc}
\frac{m}{4}+\frac{J}{l^{2}} & \frac{m}{4}-\frac{J}{l^{2}} & & \\
\frac{m}{4}-\frac{J}{l^{2}} & 2\left(\frac{m}{4}+\frac{J}{l^{2}}\right) & \ddots & \\
& \ddots & \ddots & \ddots \\
& \ddots & 2\left(\frac{m}{4}+\frac{J}{l^{2}}\right) & \frac{m}{4}-\frac{J}{l^{2}} \\
& & \frac{m}{4}-\frac{J}{l^{2}} & \frac{m}{4}+\frac{J}{l^{2}}
\end{array}\right]
$$

$$
\mathbf{K}_{\tau}=\frac{1}{l^{2}}\left[\begin{array}{ccccccc}
\tau & -2 \tau & \tau & & & & \\
-2 \tau & 5 \tau & -4 \tau & \tau & & & \\
\tau & -4 \tau & 6 \tau & \ddots & \ddots & & \\
& \tau & \ddots & \ddots & \ddots & \tau & \\
& & \ddots & \ddots & 6 \tau & -4 \tau & \tau \\
& & & \tau & -4 \tau & 5 \tau & -2 \tau \\
& & & & \tau & -2 \tau & \tau
\end{array}\right]
$$

$$
\mathbf{K}_{T}=\left[\begin{array}{llll}
k_{1} & & & \\
& k_{2} & & \\
& & \ddots & \\
& & & k_{n}
\end{array}\right]
$$

$$
\mathbf{K}=\mathbf{K}_{\tau}+\mathbf{K}_{T}
$$

行列の各要素に含まれる質量 $m$ と慣性モーメント $J$, 曲げ岡性 $\tau$ を求めるために, 図 3 に示すような薄板をリ ンクの長さと同じ幅の短冊に分割した領域を考える. 短冊の長手方向 1 次モードを正弦波の半波長と仮定して, 長手方向に縮小した場合の等価質量と等価剛性を算出した.
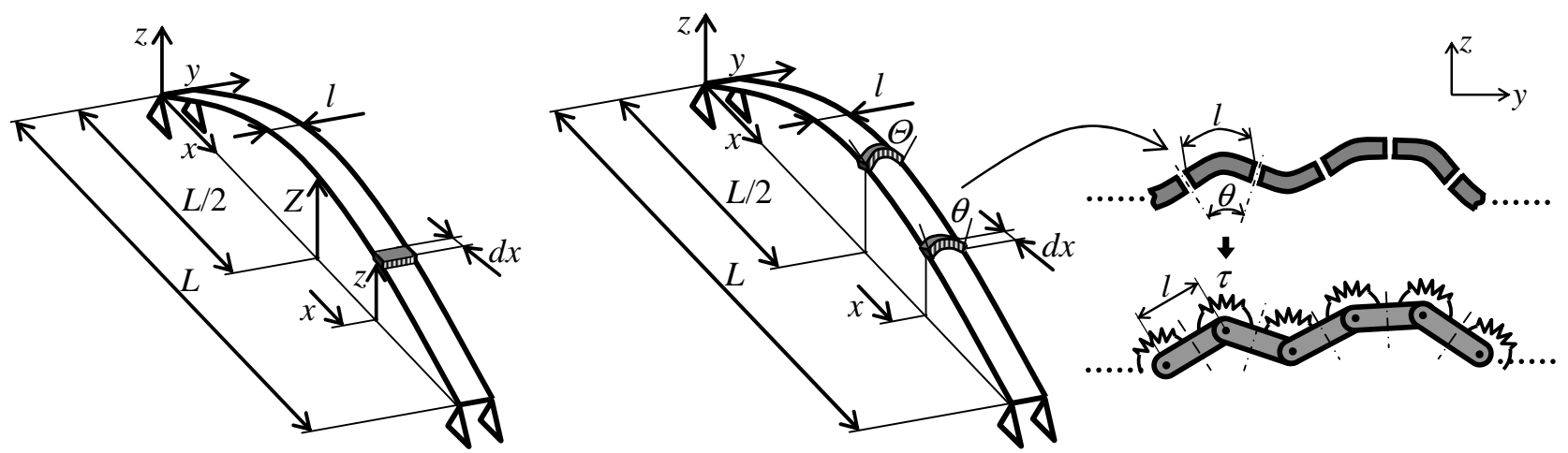

Fig.3 Equivalent mass and equivalent bending stiffness of simplified dynamic link model

短冊の支持ロール間距離を $L$, 板厚を $t$, 密度を $\rho$ とすると, 支持ロール間の中心における等価質量は長手方向 のモードを 1 次とした場合 


$$
m=\int_{0}^{L} \sin ^{2}\left(\frac{\pi}{L} x\right) \rho t l d x=\frac{\rho t l L}{\pi} \int_{0}^{\pi} \sin ^{2}(x) d x=\frac{\rho t l L}{\pi} \cdot \frac{\pi}{2}=\frac{\rho t l L}{2}
$$

により求まる. 式(7)より求めた等価質量から要素の慣性モーメントJは次式で計算される.

$$
J=\frac{m}{12}\left(t^{2}+l^{2}\right)
$$

次に, 簡易モデルのリンクの曲げ剛性 $\tau$ を計算するために短冊 1 つ当たりの幅方向の等価曲げ剛性を計算する. ねじり剛性を無視すると短冊の幅方向の曲げ剛性は梁のたわみの式よりモーメントを $M$ ，たわみ角を $\theta$ として

$$
\tau=\frac{M}{\theta}=\frac{E I_{e q}}{l}
$$

で表される． $I_{e q}$ は短冊のたわみ角が長手方向で変化することを考慮した支持ロール間の中心における等価断面二

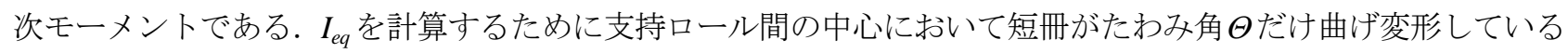
とき，長手方向の各位置におけるたわみ角 $\theta$ を次式で仮定する.

$$
\theta=\Theta \sin \left(\frac{\pi}{L} x\right)
$$

等価断面二次モーメント $I_{e q}$ による曲げひずみエネルギ $U_{e q}$ は式(9)を用いて

$$
U_{e q}=\frac{1}{2} M \Theta=\frac{E I_{e q}}{2 l} \Theta^{2}
$$

となる. 次に, 長手方向にたわみ角 $\theta$ が変化する場合の短冊のひずみエネルギを計算する．短冊の微小部分 $d x に$ おけるひずみエネルギ $d U$ は

$$
d U=\frac{E}{2 l} \cdot \frac{t^{3} d x}{12}\left\{\Theta \sin \left(\frac{\pi}{L} x\right)\right\}^{2}
$$

であり，全体のひずみエネルギ Uは式(12)を長手方向で積分することで次式のように計算される.

$$
U=\int_{0}^{L} \frac{E}{2 l} \cdot \frac{t^{3}}{12}\left\{\Theta \sin \left(\frac{\pi}{L} x\right)\right\}^{2} d x=\frac{E \Theta^{2}}{2 l} \cdot \frac{t^{3}}{12} \int_{0}^{L} \sin ^{2}\left(\frac{\pi}{L} x\right) d x
$$

式(11)および式(13)より $U_{e q}=U$ として $I_{e q}$ について解けば, 短冊全体のひずみエネルギ $U$ と等価断面二次モーメ ント $I_{e q}$ によるひずみエネルギ $U_{e q}$ が等しくなる $I_{e q}$ が求まる.

$$
I_{e q}=\frac{t^{3}}{12} \int_{0}^{L} \sin ^{2}\left(\frac{\pi}{L} x\right) d x=\frac{t^{3} L}{24}
$$

簡易モデルにおける要素間の曲げ剛性 $\tau$ は式(14)より計算された $I_{e q}$ を式(9)に代入して 


$$
\tau=\frac{E t^{3} L}{24 l}
$$

と求まる.

\section{3. 張力分布同定理論}

与えられた薄板の固有振動数と幅方向の振動モードより張力分布を求める方法について述べる. 具体的には固 有振動数と振動モードから最小二乗法によりばね分布 $k_{i}(i=1 \sim n)$ を求め, 弦の方程式を利用して各節点における剛 性値を個別に張力値に換算して張力分布を算出する方法である.

系全体の節点が同じ振動数で調和運動をしている状態として, 式(1)に示寸運動方程式の解を複素指数関数で仮 定する.

$$
z=Z e^{j \omega t}
$$

式(1)に式(16)を代入すると次式に示す一般固有值問題が得られる.

$$
\left(\omega^{2} \mathbf{M}-\mathbf{K}\right) \boldsymbol{Z}=\mathbf{0}
$$

固有值解析により式(17) を解くことで系の固有振動数と固有モードが求まる. それにより求まる薄板の固有振 動数 $\omega_{i}^{2}(i=1 \sim n)$ を対角要素とする行列を $\boldsymbol{\Omega}^{2}$, 対応するモードベクトルを列ベクトルとするモード行列を $\boldsymbol{\Phi}$ とおくと 式(18)の関係が成り立つ ${ }^{(4)}$.

$$
\mathbf{M} \boldsymbol{\Phi} \Omega^{2}=\mathbf{K} \Phi
$$

ただし

$$
\begin{aligned}
& \boldsymbol{\Omega}^{2}=\left[\begin{array}{lllll}
\omega_{1}^{2} & & & \\
& \omega_{2}^{2} & & \\
& & \ddots & \\
& & & \omega_{n}^{2}
\end{array}\right] \\
& \boldsymbol{\Phi}=\left[\begin{array}{llll}
\phi_{1} & \phi_{2} & \cdots & \phi_{n}
\end{array}\right] \\
& \boldsymbol{\phi}_{i}=\left\{\begin{array}{llll}
\phi_{i, 1} & \phi_{i, 2} & \cdots & \phi_{i, n}
\end{array}\right\}^{T}
\end{aligned}
$$

とする．式(18)に左側から $\boldsymbol{\Phi}^{T}$ を乗じると

$$
\boldsymbol{\Phi}^{T}\left(\mathbf{K}_{\tau}+\mathbf{K}_{T}\right) \boldsymbol{\Phi}=\boldsymbol{\Phi}^{T} \mathbf{M} \boldsymbol{\Phi} \mathbf{\Omega}^{2}
$$

となる. 式(22)の関係を利用して解析あるいは実験により得られる固有振動数と振動モードからばね分布を計算 する. 使用する固有振動数と振動モードベクトルは張力同定計算を行う上ではいくつでも良く，ここでは式(22)

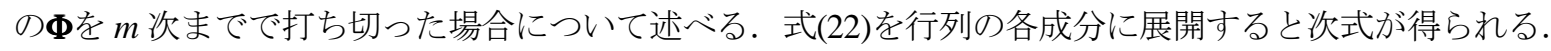




$$
\left[\begin{array}{ccc}
\boldsymbol{\phi}_{1}^{T}\left(\mathbf{K}_{T}+\mathbf{K}_{\tau}\right) \boldsymbol{\phi}_{1} & \cdots & \boldsymbol{\phi}_{1}^{T}\left(\mathbf{K}_{T}+\mathbf{K}_{\tau}\right) \boldsymbol{\phi}_{m} \\
\vdots & \ddots & \vdots \\
\boldsymbol{\phi}_{m}^{T}\left(\mathbf{K}_{T}+\mathbf{K}_{\tau}\right) \boldsymbol{\phi}_{1} & \cdots & \boldsymbol{\phi}_{m}^{T}\left(\mathbf{K}_{T}+\mathbf{K}_{\tau}\right) \boldsymbol{\phi}_{m}
\end{array}\right]=\left[\begin{array}{ccc}
\boldsymbol{\phi}_{1}^{T} \mathbf{M} \boldsymbol{\phi}_{1} \omega_{1}^{2} & & \mathbf{0} \\
& \ddots & \\
\mathbf{0} & & \boldsymbol{\phi}_{m}^{T} \mathbf{M} \boldsymbol{\phi}_{m} \omega_{m}^{2}
\end{array}\right]
$$

式(23)の両辺は対称行列であるから上三角成分または下三角成分についての $m(m+1) / 2$ 個の独立した等式が得ら れ，未知数 $\mathbf{K}_{T}$ について整理すると

$$
\left\{\begin{array}{c}
\boldsymbol{\phi}_{1}^{T} \mathbf{K}_{T} \boldsymbol{\phi}_{1} \\
\boldsymbol{\phi}_{1}^{T} \mathbf{K}_{T} \boldsymbol{\phi}_{2} \\
\vdots \\
\boldsymbol{\phi}_{1}^{T} \mathbf{K}_{T} \boldsymbol{\phi}_{m} \\
\hline \boldsymbol{\phi}_{2}^{T} \mathbf{K}_{T} \boldsymbol{\phi}_{2} \\
\boldsymbol{\phi}_{2}^{T} \mathbf{K}_{T} \boldsymbol{\phi}_{3} \\
\vdots \\
\boldsymbol{\phi}_{2}^{T} \mathbf{K}_{T} \boldsymbol{\phi}_{m} \\
\hline \vdots \\
\frac{\boldsymbol{\phi}_{m}^{T} \mathbf{K}_{T} \boldsymbol{\phi}_{m}}{\vdots}
\end{array}\right\}=\left\{\begin{array}{c}
\boldsymbol{\phi}_{1}^{T} \mathbf{M} \boldsymbol{\phi}_{1} \omega_{1}^{2}-\boldsymbol{\phi}_{1}^{T} \mathbf{K}_{\tau} \boldsymbol{\phi}_{1} \\
-\boldsymbol{\phi}_{1}^{T} \mathbf{K}_{\tau} \boldsymbol{\phi}_{2} \\
\vdots \\
\frac{-\boldsymbol{\phi}_{1}^{T} \mathbf{K}_{\tau} \boldsymbol{\phi}_{m}}{\boldsymbol{\phi}_{2}^{T} \mathbf{M} \boldsymbol{\phi}_{2} \omega_{2}^{2}-\boldsymbol{\phi}_{2}^{T} \mathbf{K}_{\tau} \boldsymbol{\phi}_{2}} \\
-\boldsymbol{\phi}_{2}^{T} \mathbf{K}_{\tau} \boldsymbol{\phi}_{3} \\
\vdots \\
-\boldsymbol{\phi}_{2}^{T} \mathbf{K}_{\tau} \boldsymbol{\phi}_{m} \\
\vdots \\
\frac{\boldsymbol{\phi}_{m}^{T} \mathbf{M} \boldsymbol{\phi}_{m} \omega_{m}^{2}-\boldsymbol{\phi}_{m}^{T} \mathbf{K}_{\tau} \boldsymbol{\phi}_{m}}{}
\end{array}\right\}
$$

のように求まる. また, 剛性行列 $\mathbf{K}_{T}$ は式(5)に示寸通り対角行列であるから, 式(24)の左辺を 1 要素について展開 し, 未知数 $k_{i}(i=1 \sim n)$ にいてまとめると, 次式に示寸ようにモードベクトル成分からなる係数ベクトルとばね分 布ベクトルとの内積の形になる.

$$
\begin{aligned}
\boldsymbol{\phi}_{i}^{T} \mathbf{K}_{T} \boldsymbol{\phi}_{j} & =\phi_{i, 1} \phi_{j, 1} k_{1}+\phi_{i, 2} \phi_{j, 2} k_{2}+\cdots+\phi_{i, n} \phi_{j, n} k_{n} \\
& =\left\{\begin{array}{llllll}
\phi_{i, 1} \phi_{j, 1} & \phi_{i, 2} \phi_{j, 2} & \cdots & \phi_{i, n} \phi_{j, n}
\end{array}\right\} \cdot\left\{\begin{array}{lllll}
k_{1} & k_{2} & \cdots & k_{n}
\end{array}\right\}^{T}
\end{aligned}
$$

式(25)を用いて式(24)の左辺を整理すると既知の係数行列と未知のばね分布ベクトルとの積となる.

$\left[\begin{array}{cccc}\phi_{1,1}^{2} & \phi_{1,2}^{2} & \cdots & \phi_{1, n}^{2} \\ \phi_{1,1} \phi_{2,1} & \phi_{1,2} \phi_{2,2} & \cdots & \phi_{1, n} \phi_{2, n} \\ \vdots & \vdots & & \vdots \\ \phi_{1,1} \phi_{m, 1} & \phi_{1,2} \phi_{m, 2} & \cdots & \phi_{1, n} \phi_{m, n} \\ \hline \phi_{2,1}^{2} & \phi_{2,2}^{2} & \cdots & \phi_{2, n}^{2} \\ \phi_{2,1} \phi_{3,1} & \phi_{2,2} \phi_{3,2} & \cdots & \phi_{2, n} \phi_{3, n} \\ \vdots & \vdots & & \vdots \\ \phi_{2,1} \phi_{m, 1} & \phi_{2,2} \phi_{m, 2} & \cdots & \phi_{2, n} \phi_{m, n} \\ \hline \vdots & \vdots & & \vdots \\ \hline \phi_{m, 1}^{2} & \phi_{m, 2}^{2} & \cdots & \phi_{m, n}^{2}\end{array}\right]\left\{\begin{array}{c}\boldsymbol{\phi}_{1}^{T} \mathbf{M} \boldsymbol{\phi}_{1} \omega_{1}^{2}-\boldsymbol{\phi}_{1}^{T} \mathbf{K}_{\tau} \boldsymbol{\phi}_{1} \\ -\boldsymbol{\phi}_{1}^{T} \mathbf{K}_{\tau} \boldsymbol{\phi}_{2} \\ \vdots \\ k_{2} \\ \vdots \\ k_{n}\end{array}\right\}=\left\{\begin{array}{c}-\boldsymbol{\phi}_{1}^{T} \mathbf{K}_{\tau} \boldsymbol{\phi}_{m} \\ \frac{\boldsymbol{\phi}_{2}^{T} \mathbf{M} \boldsymbol{\phi}_{2} \omega_{2}^{2}-\boldsymbol{\phi}_{2}^{T} \mathbf{K}_{\tau} \boldsymbol{\phi}_{2}}{-\boldsymbol{\phi}_{2}^{T} \mathbf{K}_{\tau} \boldsymbol{\phi}_{3}} \\ \vdots \\ -\boldsymbol{\phi}_{2}^{T} \mathbf{K}_{\tau} \boldsymbol{\phi}_{m} \\ \vdots \\ \frac{\boldsymbol{\phi}_{m}^{T} \mathbf{M} \boldsymbol{\phi}_{m} \omega_{m}^{2}-\boldsymbol{\phi}_{m}^{T} \mathbf{K}_{\tau} \boldsymbol{\phi}_{m}}{2}\end{array}\right\}$


式(26)の未知ベクトルについて最小二乗法で解けばばね分布を求めることができる. 式(26)の左辺における係数 行列を $\boldsymbol{\Phi}_{k}$, 未知ベクトルを $\boldsymbol{k}_{T}$, 右辺の既知ベクトルを $\boldsymbol{k}_{\boldsymbol{\omega}}$ とすると

$$
\boldsymbol{\Phi}_{k} \boldsymbol{k}_{T}=\boldsymbol{k}_{\omega}
$$

で表され，最小二乗法は $\boldsymbol{\Phi}_{k}$ の擬似逆行列 $\boldsymbol{\Phi}_{k}^{\dagger}$ 用いて

$$
\begin{aligned}
& \boldsymbol{k}_{T}=\boldsymbol{\Phi}_{k}^{\dagger} \boldsymbol{k}_{\omega} \\
& \boldsymbol{\Phi}_{k}^{\dagger}=\left(\boldsymbol{\Phi}_{k}^{T} \boldsymbol{\Phi}_{k}\right)^{-1} \boldsymbol{\Phi}_{k}^{T}
\end{aligned}
$$

となる. 式(28)より求まった值はばね分布であるから, 次に張力分布に換算する方法について述べる. 図 3 に示 した短冊の領域において板厚が薄く長手 1 次モードしか考慮しない場合には, 張力による幾何剛性に対して長手 方向の曲げ岡性は無視できる程度となる．これにより 1 つの短冊を張力の作用した弦とみなし，長手方向のモー ドを正弦波の半波長として弦中央部の等価質量と等価剛性による 1 自由度系に近似する. そうすればばね分布と 張力分布の換算式は次式に示寸弦の張力と 1 次の固有振動数の関係式より求めることができる.

$$
f_{1}=\frac{1}{2 L} \sqrt{\frac{T}{\rho A}}
$$

式(30)を $T$ について解き， $f_{1}$ を等価質量 $m$ と節点 $i$ におけるばね分布 $k_{i}$ の 1 要素からなる 1 自由度系の固有振 動数として, 次式に示寸ようなばね分布 $k_{i}$ から張力分布 $T_{i}$ への換算式を得る.

$$
T_{i}=\rho t l\left(2 L f_{1}\right)^{2}=\rho t l \frac{L^{2}}{\pi^{2}}\left(2 \pi f_{1}\right)^{2}=\rho t l \frac{L^{2}}{\pi^{2}} \cdot \frac{k_{i}}{m}=\frac{\rho t l L}{m} \cdot \frac{L}{\pi^{2}} k_{i}
$$

式(7)により式(31)から $m$ を消去すると

$$
T_{i}=\frac{2 L}{\pi^{2}} k_{i} \quad(i=1,2, \cdots, n)
$$

が得られる. 式(32)で計算された張力分布を合計することで総張力が求まる. また，式(32)により得られた張力は 節点ごとの值であるので次式により要素ごとの值に変換する.

$$
\hat{\boldsymbol{T}}=\left\{\begin{array}{lllll}
T_{1}+\frac{T_{2}}{2} & \frac{T_{2}+T_{3}}{2} & \cdots & \frac{T_{n-2}+T_{n-1}}{2} & \frac{T_{n-1}}{2}+T_{n}
\end{array}\right\}^{T}
$$

ところで, 計算に使用するモード数が少ない場合や幅方向の分割数が大きい場合は行列 $\boldsymbol{\Phi}_{k}$ のランクが不足し, 式(28)の解が実際の張力分布と一致しなくなることがある. そこで, 特異值分解を利用して望ましい解を求める 方法について述べる. 係数行列 $\boldsymbol{\Phi}_{k}$ は特異ベクトルを列ベクトルとする直交行列 $\mathbf{P}$ と $\mathbf{Q}$, 特異值を対角成分に持つ 対角行列Dを用いて

$$
\mathbf{\Phi}_{k}=\mathbf{P D Q} \mathbf{Q}^{T}
$$

と分解できる(5). ただし， $\mathbf{Q}^{T}$ は $\mathbf{Q}$ の転置行列である． $\mathbf{D}$ を特異值の大きい部分行列 $\mathbf{D}_{s}$ と特異值の小さい部分行 列 $\mathbf{D}_{n}$ に分けると $\boldsymbol{\Phi}_{k}$ は 


$$
\mathbf{\Phi}_{k}=\left[\begin{array}{ll}
\mathbf{P}_{s} & \mathbf{P}_{n}
\end{array}\right]\left[\begin{array}{cc}
\mathbf{D}_{s} & \mathbf{0} \\
\mathbf{0} & \mathbf{D}_{n}
\end{array}\right]\left[\begin{array}{c}
\mathbf{Q}_{s}^{T} \\
\mathbf{Q}_{n}^{T}
\end{array}\right] \approx\left[\begin{array}{ll}
\mathbf{P}_{s} & \mathbf{P}_{n}
\end{array}\right]\left[\begin{array}{cc}
\mathbf{D}_{s} & \mathbf{0} \\
\mathbf{0} & \mathbf{0}
\end{array}\right]\left[\begin{array}{c}
\mathbf{Q}_{s}^{T} \\
\mathbf{Q}_{n}^{T}
\end{array}\right]=\mathbf{P}_{s} \mathbf{D}_{s} \mathbf{Q}_{s}^{T}
$$

と近似できる. 式(35)で特異值 $\mathbf{D}_{s}$ には必要な信号成分, 微小な特異值 $\mathbf{D}_{n}$ にはノイズや計算誤差等により生じる成 分が含まれると考えられる. 微小成分 $\mathbf{D}_{n}$ を除去した式(35)により， $\boldsymbol{\Phi}_{k}$ の擬似逆行列は次式のように近似される.

$$
\boldsymbol{\Phi}_{k}^{\dagger}=\mathbf{Q}_{s} \mathbf{D}_{s}^{-1} \mathbf{P}_{s}^{T}
$$

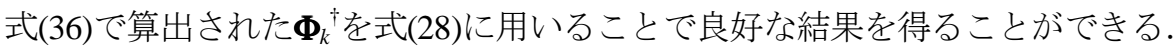

\section{FEM 解析結果への適用}

提案した張力分布同定理論を薄板の FEM 解析結果に対して適用し，精度を検証した結果について述べる. 本 論文では形状不良の代表例として中伸びと片伸び，耳波の場合について検証する．ここでいう中伸びとは板幅方 向の中央部において板のゆがみによる波形状が長手方向に一様に発生しているような形状である.また，片伸び は板幅方向の端部においてゆがみが発生しているような形状であり，ゆがみが板の両端で発生している場合は耳 波と呼ぶ. 図 4 にゆがみ分布として中伸びと片伸び，耳波をそれぞれ設定した FEM モデルを示す．図 4 の FEM モデルは実モデルよりゆがみ形状をわかりやすくするため $z$ 方向に 10 倍に拡大してある.

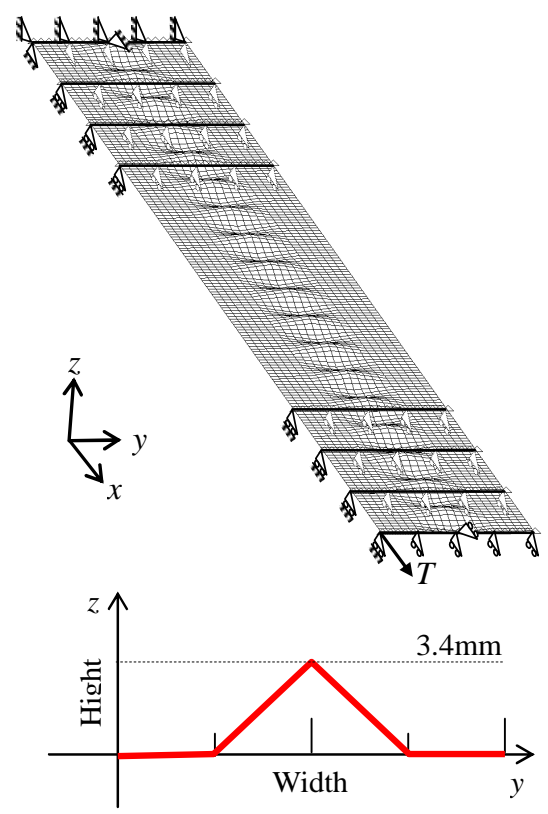

(a) Center buckle

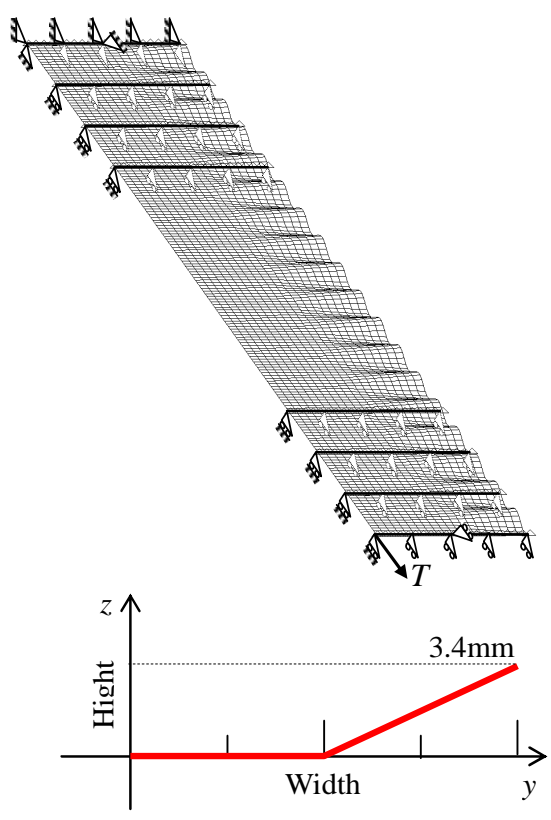

(b) Edge buckle (one side)

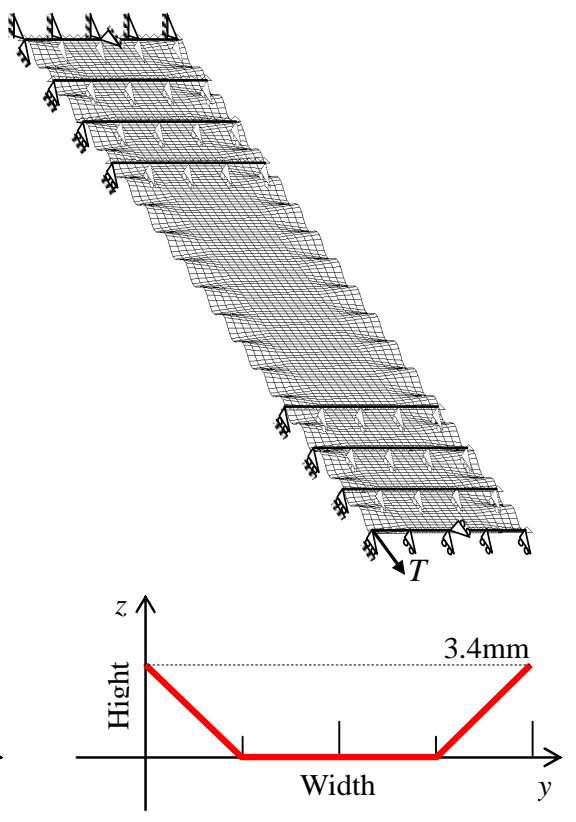

(c) Edge buckle (both sides)

Fig.4 FEM models of various strain patterns of plate

モデルはアルミ薄板とし, 寸法と物性は厚さ $0.5 \mathrm{~mm}$, 幅 $1 \mathrm{~m}$, 全長 $9 \mathrm{~m}$, 支持ロール間隔 $4.5 \mathrm{~m}$, 密度 $2700 \mathrm{~kg} / \mathrm{m}^{3}$, ヤング率 $70 \mathrm{GPa}$ ，ポアソン比 0.3 とした。提案手法の精度検証は図 4 に示す 3 種類のゆがみ分布と比較用の形状 不良のない平坦な板モデルも含めた 4 条件で行った. 各ゆがみ分布の波形状は図 4 に示寸通り振幅 $3.4 \mathrm{~mm}$ を最大 值とした幅方向に直線的な分布とし, 長手方向は周期 $500 \mathrm{~mm}$ の正弦波となるような形状とした. 境界条件は張 力を付加した板端側に $z$ 方向の拘束, $x$ 方向は巻き取りリールあるいは駆動ロールなどにより一様に引っ張られ た状態を模擬するために節点間の相対変位が生じないような拘束を設定した．これにより一つの節点に張力を設 定するだけで，板の総張力が設定張力と等しくなるような幅方向に一様な強制変位を与えたことに相当する解析 結果が得られる. また，固定端となる反対側の板端部は $x$ 方向と $z$ 方向を拘束した単純支持とした. それと, 板 
の途中に通板ロールを模擬した $z$ 方向拘束を 6 箇所設定した. 図 4 中の拘束は図示するために幅方向 5 箇所ずつ となっているが実際のモデルの拘束は幅方向の全節点である. $y$ 方向の拘束については剛体モードを除去するた めに板端部の中央に一節点だけ加えた. また, FEM モデルのメッシュは一辺が $5 \mathrm{~mm}$ の正方形とした.

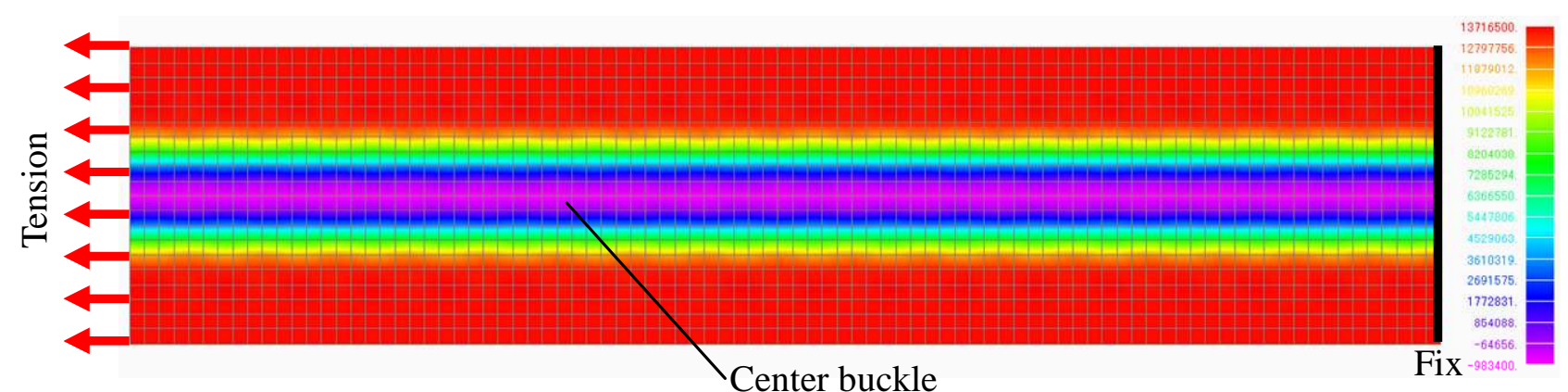

Fig.5 Stress contour map in plate in the case of Center buckle

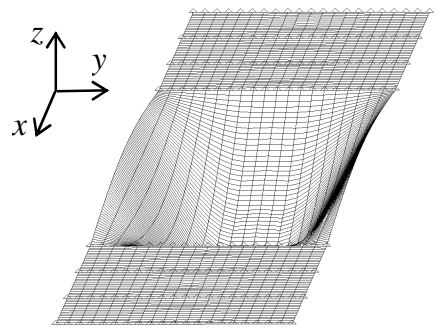

(a) mode $1(5.79 \mathrm{~Hz})$

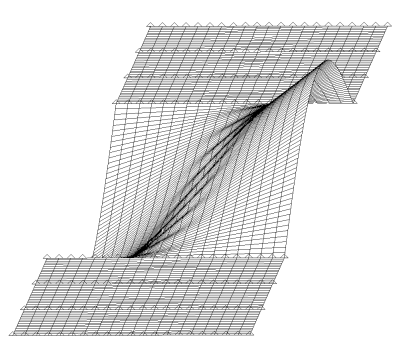

(b) mode $2(7.85 \mathrm{~Hz})$

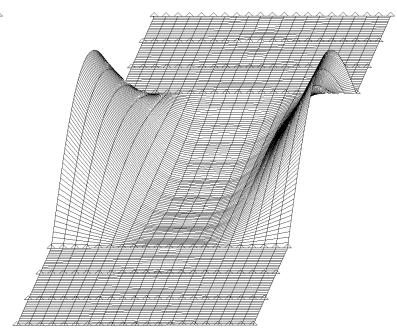

(c) mode $3(8.46 \mathrm{~Hz})$

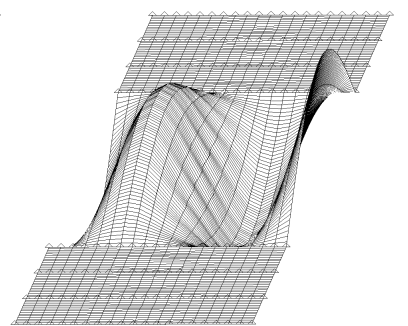

(d) mode $4(10.8 \mathrm{~Hz})$

Fig.6 Natural vibration mode of thin plate in the case of center buckle

図 5 は張力を $4900 \mathrm{~N}$ に設定して静解析を行った中伸び薄板の応力分布である. 板幅方向中央部の応力が低下し ており，ゆがみ形状に対応した応力分布が生じていることがわかる．図 5 の状態で発生している幾何剛性を考慮 して固有值解析を行った結果を図 6 に示寸. 張力同定計算には長手方向中央部における幅方向の振動モードを使 用した。

図 7 に式(29)に示した擬似逆行列を用いた場合と式(36)に示した特異值分解を用いた場合の中伸び張力分布の 同定結果を示す. 同定計算には図 6 に示した 1 次から 4 次の幅方向振動モードを使用し、簡易モデルは 11 自由度 とした。図7(a)に示す通り式(29)の最小二乗法では同定結果に大きな誤差が生じているのに対し，特異値分解によ り絶対值の小さい特異值を除去した場合は FEM 結果と良く一致していることがわかる. 図 7(b)は係数行列 $\boldsymbol{\Phi}_{k}$ の 特異值分解結果で 10 個の特異值のうち $\sigma_{8} \sim \sigma_{10}$ は值がほぼ 0 となっており, 式(35)の特異值は $\mathbf{D}_{s}=\operatorname{diag}\left(\sigma_{1}, \cdots, \sigma_{7}\right)$, $\mathbf{D}_{n}=\operatorname{diag}\left(\sigma_{8}, \cdots, \sigma_{10}\right)$ となる. 式(29)の擬似逆行列で大きな同定誤差を生じているのは $\boldsymbol{\Phi}_{k}^{\dagger}$ が計算される過程で特異値 が大きい信号成分に対して相対的に特異值が小さい誤差成分が逆数 $\mathbf{D}_{n}^{-1}$ により拡大されたことが原因と考えられ る.これに対し，提案手法では特異值の小さい誤差成分を分離し，擬似逆行列を計算する際に除去しているため 良好な結果を得ることができる. 


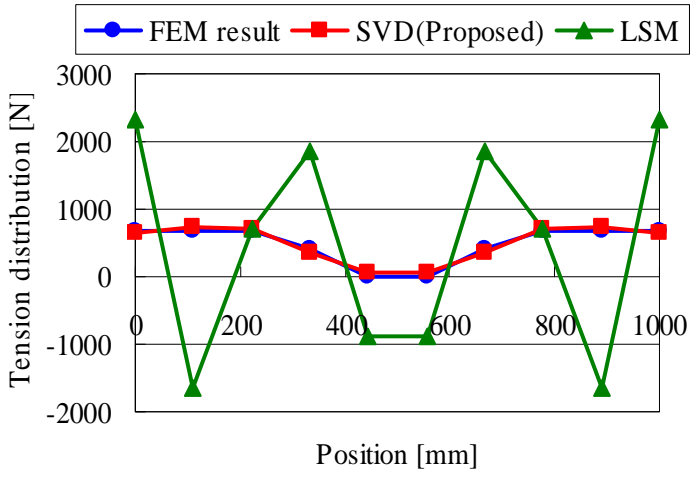

(a) Identification results

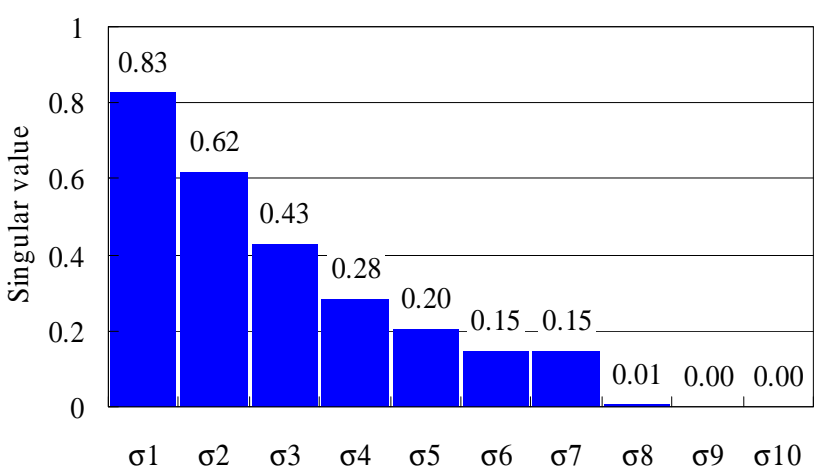

(b) SVD results

Fig.7 Comparison of least squared method with proposed SVD method

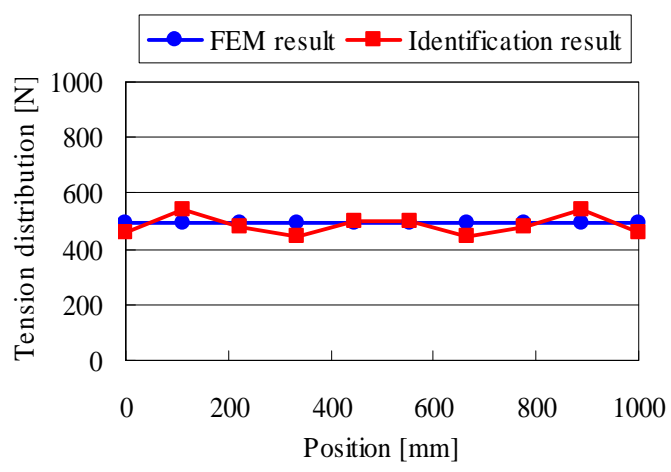

(a) Flat

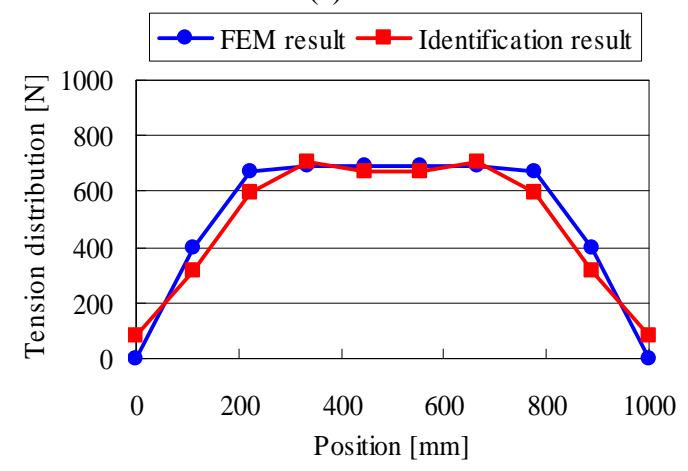

(c) Edge buckle (both sides)

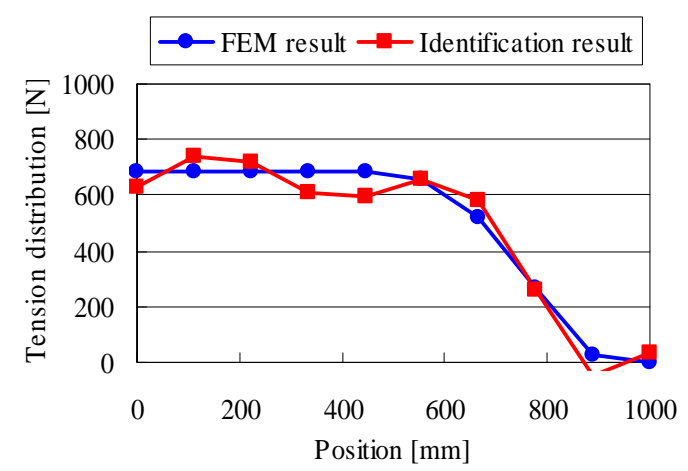

(b) Edge buckle (one side)

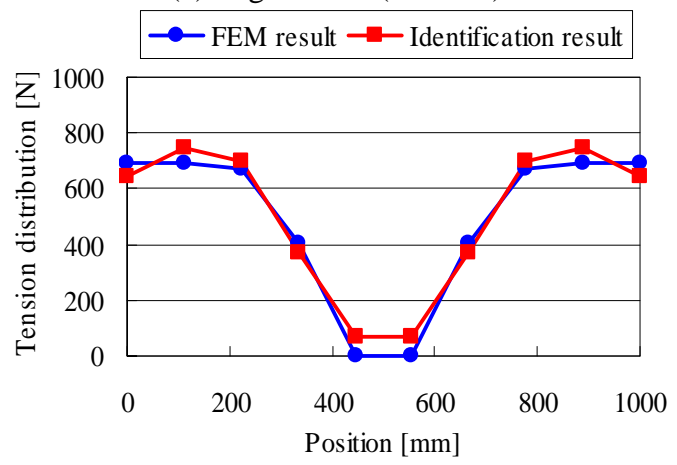

(d) Center buckle

Fig.8 Identification results of tension distribution

図 8 に各ゆがみ分布の FEM 固有值解析結果から張力分布を同定した結果を示寸. 図 8(a)はゆがみのない平坦な 板で張力分布は幅方向に一様となる. 図 8(b)は片伸び板の張力分布でゆがみによる波形状が現れている部分の張 力が下がり, 図 8(c), (d)はそれぞれ耳波と中伸びの張力分布でゆがみに対応して板両端部と板中央部の張力が下 がっている. 図 8 より平坦な板と代表的なゆがみ条件である片伸び，耳波，中伸びにおいては解析結果の張力分 布と同定結果がよく一致していることがわかる．ただし，本手法において精度の良い同定を行うための制約とし て，採用する振動モードの節が同じ点に重ならないように注意する必要がある．これは採用した全てのモードの 節が重なるような領域が生じると，その領域における張力の情報が採用したモードの形状と固有振動数に含まれ ていないことから張力同定精度が悪化するためである，この点については，後述する採用モードの組み合わせを 変化させて張力同定を行った結果を評価するところで具体的に述べる. 
図 9 に張力同定に用いた簡易モデルのパラメータで固有值解析を行って得られた振動モードを示す. 張力分布 を表すばね分布 $k_{i}$ は板が平坦で一様な張力分布が発生しているとして, 式(32)よりばね定数を計算して設定した.

図 10 は図 9 に示した振動モードを用いて剛性行列の張力成分である $\mathbf{K}_{T}$ と幅方向曲げ剛性成分 $\mathbf{K} \tau$ て モード剛性 に対する寄与度を計算した結果である. 図 10 より 1 4 次までの低次のモードではモード岡性に対する張力の寄 与が 50\%以上と大きく, 逆に6 次以上の高次のモードでは 10\%以下と小さくなっていることがわかる. これは図 9 より明らかなように，低次のモードでは節の数が少なく曲げがほとんど作用していないのに対し，高次のモー ドでは多くの節と腹を持つ曲がりの多い形状となっているためである. したがって張力同定を行う場合はなるべ く張力の寄与度の大きい低次の振動モードを用いるのが望ましく, 特に 1 4 次モードを使用すると精度のよい同 定が行えると考えられる.なお, 図 10 に示した張力と曲げ剛性の寄与の割合は付加した張力值や板の曲げ岡性值, 板のゆがみ形状によって変化するが，高次になるほど張力の寄与が低くなる傾向はほぼ同じである．また，実際 のモード計測では一般的に高次になるほど測定が難しくなるため，本技術には張力の寄与が大きく測定の容易な 低次のモードを選択的に使用できるという利点があるといえる.

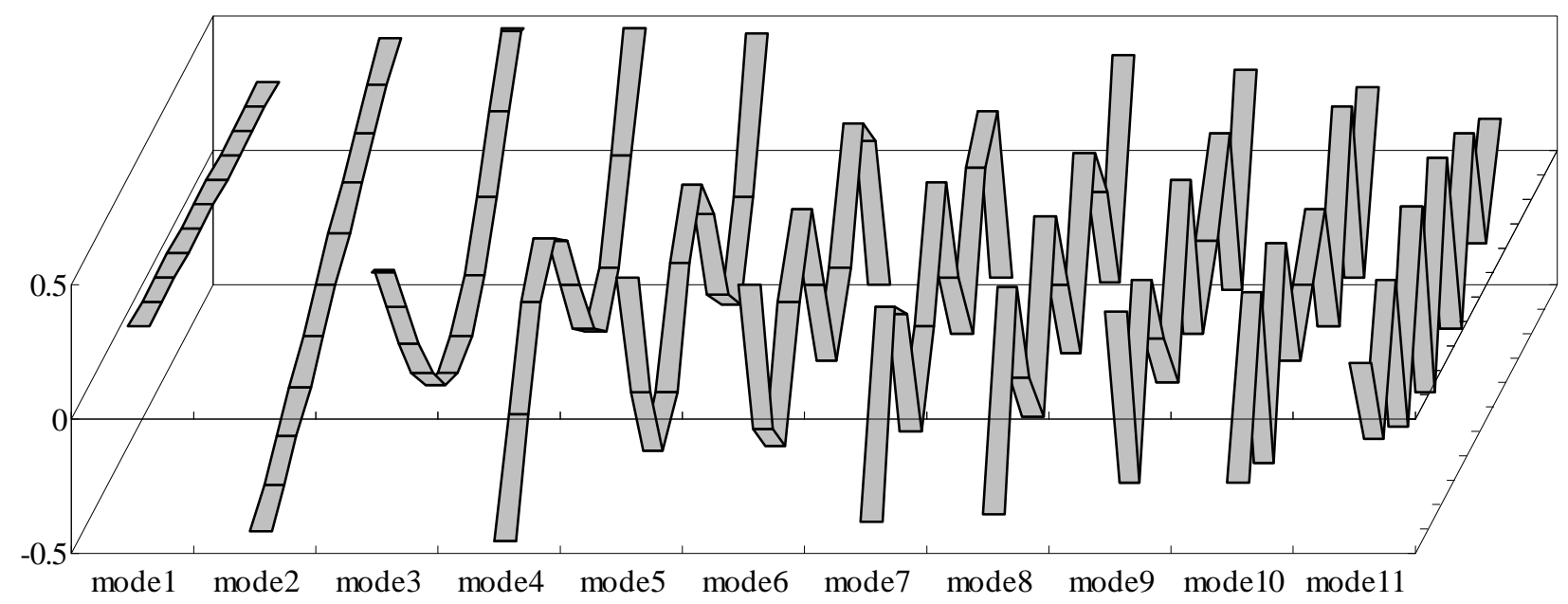

Fig. 9 Mode shape of simplified dynamic link model

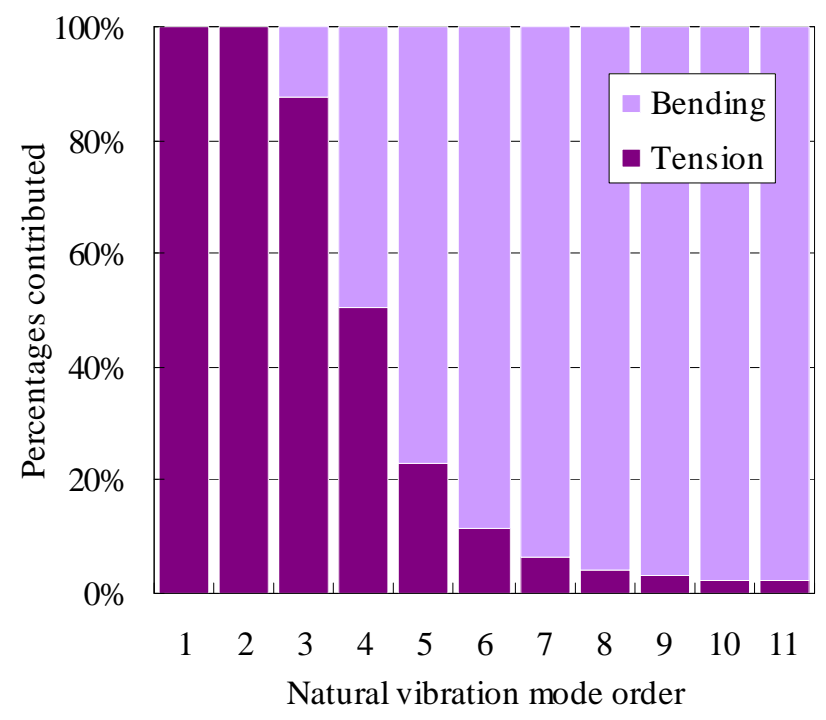

Fig. 10 Contributions of modal stiffness 


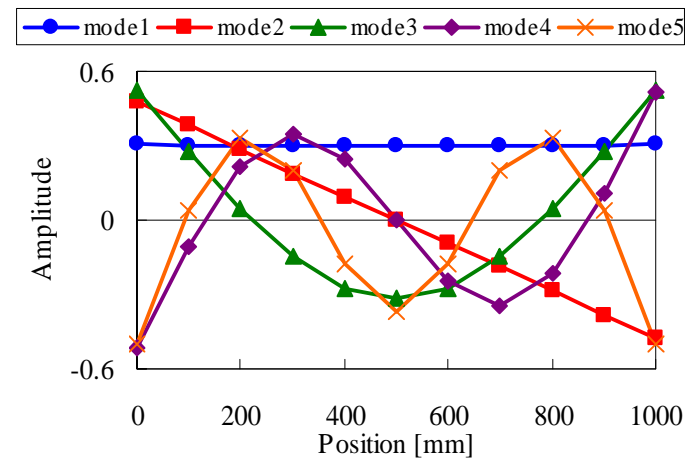

(a) Mode shape

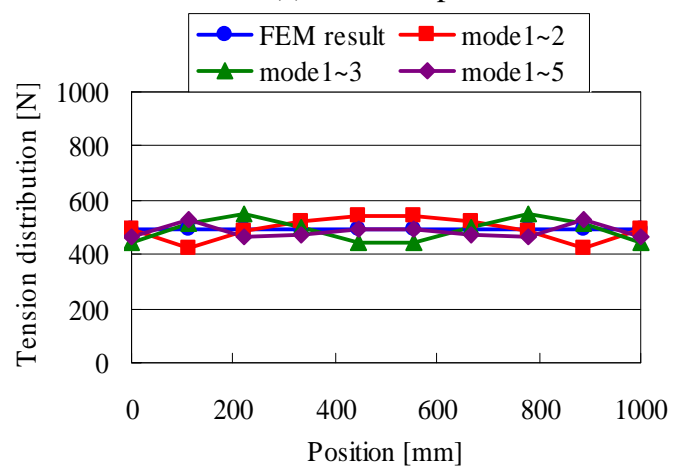

(b) Various number of the mode

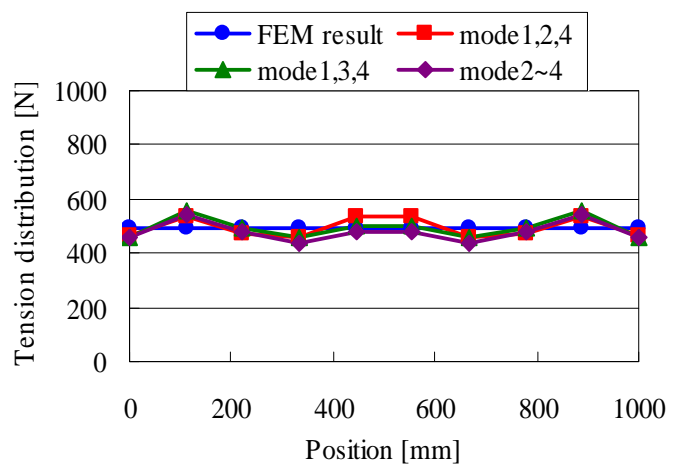

(c) Influence of lack of the mode

Fig. 11 Identification results of flat plate

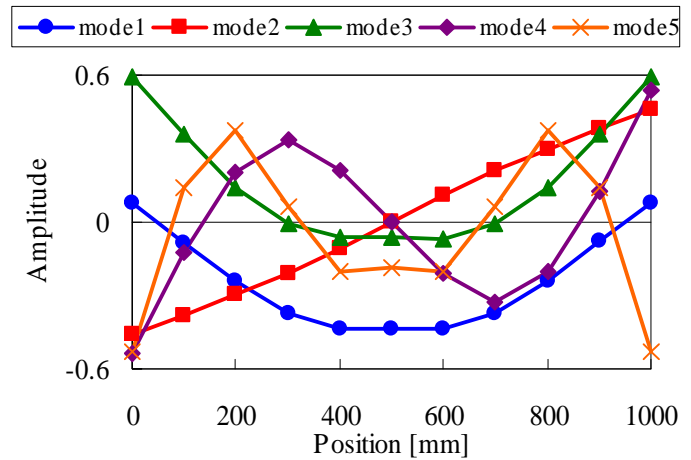

(a) Mode shape

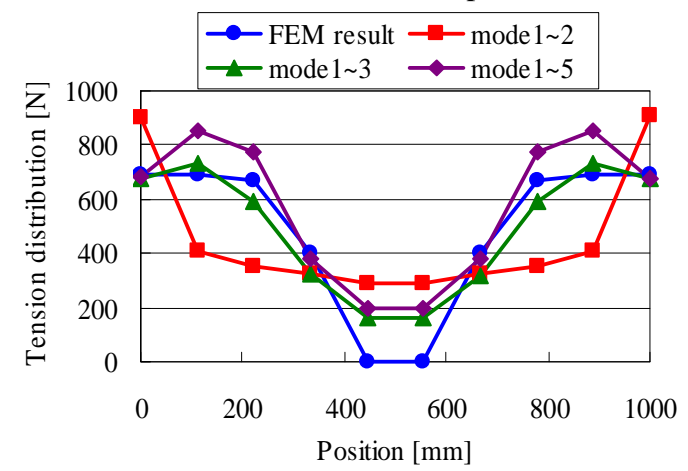

(b) Various number of the mode

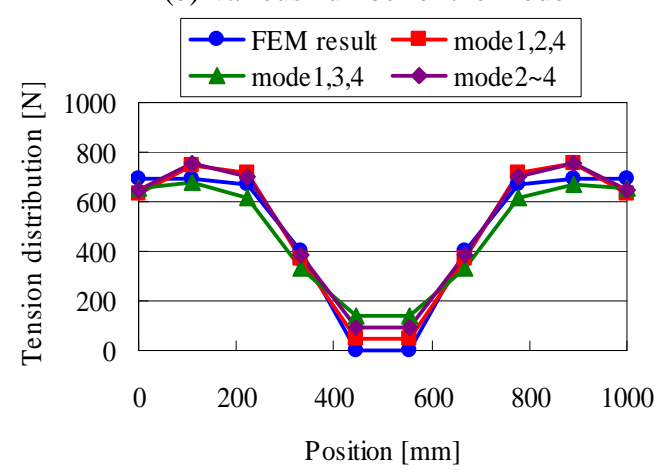

(c) Influence of lack of the mode

Fig. 12 Identification results in the case of Center buckle

次に，同じ薄板 FEM モデルの解析結果を使用して張力同定計算に採用するモードの数と組み合わせを変えた 場合の張力同定結果を図 11〜図 14 に示す. 図 11 はゆがみのない平坦な薄板モデルで張力同定を行った結果であ る. 図 11(a)は FEM 解析で得られた 1 5 次の板幅方向の振動モードで, 図 11(b)は 1 2 次，1 3 次および 1 5 次 モードを使用した場合の同定結果である. 図 11(c)は 1 次〜4 次モードの内， 3 次モードまたは 2 次モード， 1 次 モードのいずれか一つが欠けた場合の同定結果である. 図 11(b)より平坦な板では図 8(a)の結果も含めると, 検証 した範囲ではどのようなモードの組み合わせであってもほぼ同等の同定精度が得られている. また, 図 11(c)より 途中のモードが 1 つ欠けた場合であっても問題なく同定が可能であることがわかる. その理由として式(26)の元 となっている式(18)が振動モードと固有振動数の数によらず，組み合わせが適切であれば成り立つことによるも のと考えられる.

図 12 に同様の条件で中伸び板に対して張力同定を行った結果を示寸. 図 12(b)より中伸びの場合, 採用モード を 1 次と 2 次にした場合の同定結果の分布は答えとなる FEM 解析結果の分布との差がかなり大きくなっている ことがわかる. これは同定しょうとしている張力分布に対し固有振動数と振動モードの情報が不足していること によるものと考えられる. 図 12(c)は 1 次〜4 次モードの内，一つのモードが欠けた場合の同定結果で，中伸びの 場合も図11(c)と同様に途中のモードが欠けても精度良く同定できていることがわかる. 


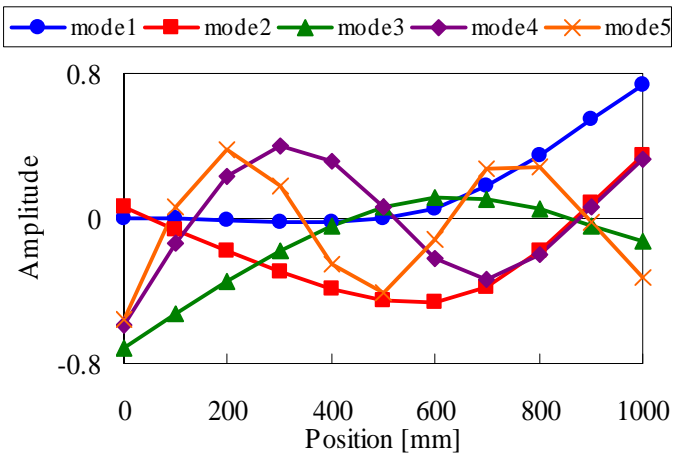

(a) Mode shape

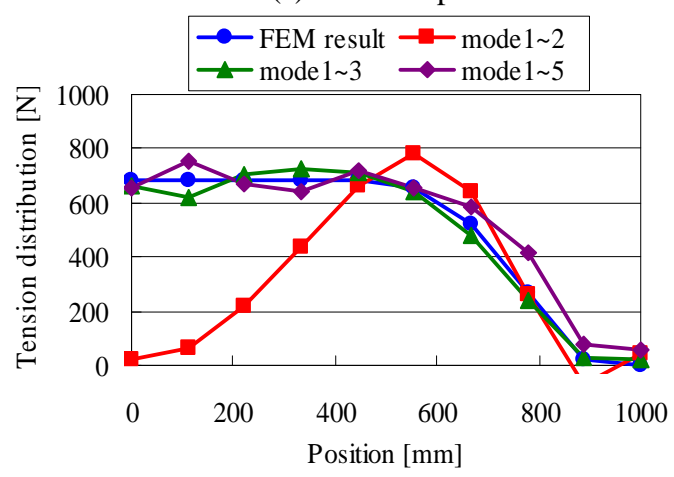

(b) Various number of the mode

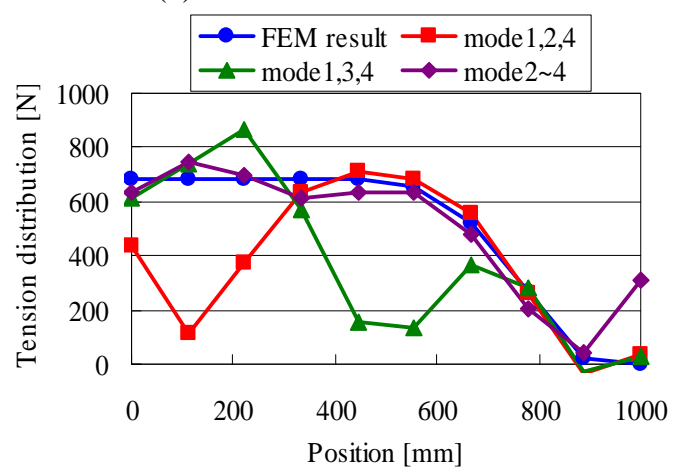

(c) Influence of lack of the mode

Fig. 13 Identification results in the case of Edge buckle (one side)

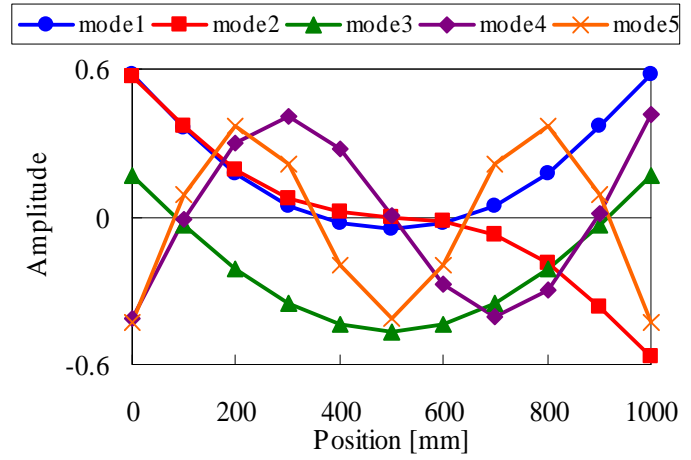

(a) Mode shape

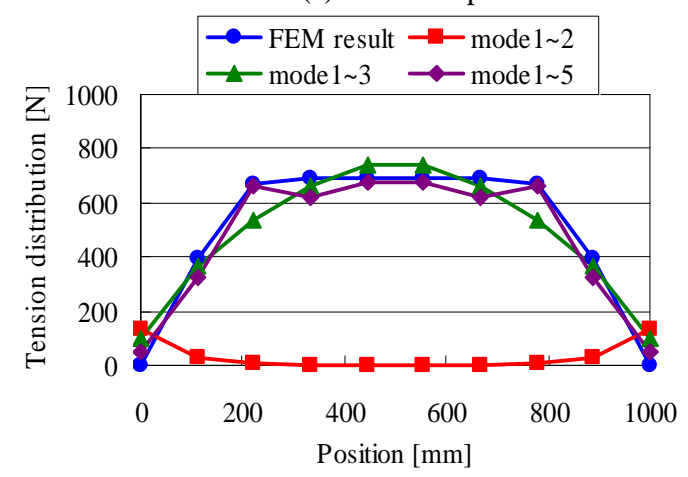

(b) Various number of the mode

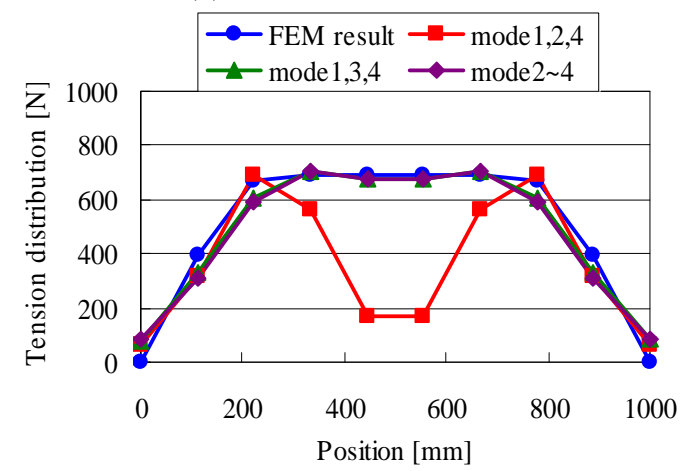

(c) Influence of lack of the mode

Fig. 14 Identification results in the case of Edge buckle (both sides)

図 13 および図 14 は片伸びと耳波についてモード数を变えて張力同定を行った結果である. 図 13(b) と図 14(b) よりどちらも図 12(b)の中伸びの場合と同様にモードの組み合わせを 1 次と 2 次とした場合は同定精度が悪化して おり，それ以外のモードの組み合わせでは比較的精度良く同定できていることがわかる. また，図 13(c) と図 14(c) より特定の次数のモードが欠けると同定精度が悪化する場合があることが確認される. 図 13(c)の片伸びでは 3 次 または 2 次モード, 図 14(c)の耳波では 3 次モードが欠けた場合に実際の張力分布と大きく異なる波形となってい る.ここで同定精度が悪化する原因として図 13(a) と図 14(a)のモード形状に着目すると, 例えば図 13(c)に示す片 伸びの mode 1,2,4 では答えである FEM 值に対して幅方向位置 0 200[mm]の範囲で張力分布が過小に同定されて おり, これは図 13(a)の 1 次と 2 次, 4 次モードでは節にあたる部分である. また, 図 14(c)に示す耳波の mode 1,2,4 では 400 600[mm]の範囲で張力分布が小さくなっており，この場合も図 14(a)で採用したモードの節に相当する部 分である.つまり採用したモードの節が重なる位置では張力分布の同定精度が下がる傾向にあることがわかる. これは本手法が固有振動数と振動モードへの幾何剛性の寄与を利用して張力分布を求めているため, モードの振 幅情報が小さい部分の精度が低下寸ることによるものと考えられる．したがって張力分布を精度良く同定するた めには各モードの腹と節が幅方向にまんべんなく分布していることが望ましいと考えられる. 
参考までに張力分布同定計算に使用した特異值数を表 1 に示寸. 最大特異值に対して採用する特異値と採用し ない特異値との適切な閾值は良く分かっていないが，表 1 については最大特異值の $5 \%$ 以上の値を目安に採用特 異值を選択し，同定結果を評価しつつ最も FEM 解析結果に近くなる特異值数を採用した．表 1 より特異值数は 採用モード 2 つの場合は $2 \sim 3$, 採用モード 3 つの場合は $5 \sim 6$, 採用モード 4 つの場合は 7 , 採用モード 5 つの場 合は 8〜9 となっており, 採用モード数の増加に対応して採用特異值数が増える傾向にあることが分かる.ただし, 同じ採用モード数であってもモードの組み合わせによって採用特異値の数は若干異なる.

Table 1 Number of singular values used for the identification of tension distribution

\begin{tabular}{c|cccc}
\hline & flat & $\begin{array}{c}\text { Edge buckle } \\
\text { (one side) }\end{array}$ & $\begin{array}{c}\text { Edge buckle } \\
\text { (both sides) }\end{array}$ & $\begin{array}{c}\text { Center } \\
\text { buckle }\end{array}$ \\
\hline mode 1,2,4 & 6 & 5 & 5 & 6 \\
mode 1,3,4 & 6 & 5 & 6 & 6 \\
mode 2,3,4 & 6 & 5 & 6 & 5 \\
mode 1 2 & 3 & 3 & 2 & 3 \\
mode 1 3 & 5 & 5 & 5 & 5 \\
mode 1 4 & 7 & 7 & 7 & 7 \\
mode 1 5 & 9 & 8 & 9 & 8 \\
\hline
\end{tabular}

\section{5. 結 語}

ゆがみのある薄板の振動特性から幅方向の張力分布を同定する技術を開発した．本手法は薄板を長手方向に縮 小した簡易モデルを作成したことで，板全面ではなく幅方向の振動モードのみが得られれば良く，少ない計測点 と計算量で張力分布を同定することができる. また，簡易モデルの質量行列と剛性行列を板の寸法と物性より求 めるため，鉄や銅，アルミ，その他の材料も含めた広範な薄板製品に適用することが可能である. 張力分布同定 理論では簡易モデルで得られた既知行列を利用寸ることで, 固有振動数と振動モードから最小二乗法により張力 分布を求める手法を提案した．また，計測点と比較して同定計算に使用する振動モード数が少ない場合でも，特 異值分解を利用寸ることで張力分布の分割数を減らすことなく良好な同定結果を得られる方法を示した. 提案手 法を検証するため代表的なゆがみ分布である片伸びと中伸び，耳波を再現した薄板の FEM モデルを作成し，張 力を付加した状態での固有值解析で得られた 1 次〜 4 次までの固有振動数と幅方向の振動モードを用いて張力分 布を同定した. その結果, FEM の静解析より得られた張力分布と提案手法による同定結果がよく一致し, 本手法 の妥当性を示した.さらには張力同定に用いるモードの組み合わせを変化させた場合の同定精度についての検討 も行い, 適切なモードの組み合わせを選択寸れば途中の次数のモードが久けても精度の良い同定結果が得られる ことを示した．また，本手法では採用されたモードの節が重なる部分では張力の同定精度が悪化することがわか った.

\section{文献}

（1）安部可治，長尾幸男，浜崎芳治，白石橿，“板圧延の理論と実際”，日本鉄鋼協会，(1984), p. 264.

（2）松井健一，山本章生，橘，秀文，“熱間圧延用平坦度計の実用化”, The Iron and Steel Institute of Japan, (1988), pp. 1817-1823.

（3）上田宏樹, 坂谷亨, 原田宗和, 宇津野秀夫, “振動法による非接触板張力計測技術”, 神戸製鋼技報, Vol. 56, No. 1, (2006), pp. 59-63.

（4）長松昭男，“モード解析”，倍風館，(1985)，pp. 56-57.

(5) 三澤正吉，狼嘉彰，"特異值分解のシステム同定への適用”, 日本機械学会論文集 C 編, Vol. 65, No. 634(1999), pp. 2235-2242. 